\title{
ANALISIS PERENCANAAN PRODUKSI PADA PT. ARMSTRONG INDUSTRI INDONESIA DENGAN METODE FORECASTING DAN AGREGAT PLANNING
}

\author{
Fristha Ayu Reicita \\ Teknik Industri, Fakultas Sains dan Teknologi, Universitas Al-Azhar Indonesia \\ e-mail: fristhaayureicita@gmail.com
}

\begin{abstract}
ABSTRAK
Pada umumnya masalah yang sering muncul tiap perusahaan termasuk PT. Armstrong Industri Indonesia adalah mengalami kendala dalam merencanakan jumlah produksi sesuai kapasitas produksi sehingga penelitian ini bertujuan untuk menentukan metode peramalan yang tepat dan strategi agregat yang sesuai untuk digunakan dalam perencanaan produksi pada produk Insulation Sheet A, Foot, dan Wire Harness Tie L-80 yang memiliki permintaan berfluktuasi. Metode yang digunakan untuk melakukan peramalan pada ketiga produk tersebut adalah Single Moving Average dan Single Exponential Smoothing, sedangkan untuk perencanaan agregat strategi yang digunakan antara lain Chase Strategy, Level Strategy dan Mixed Strategy yang kemudian dipilih strategi terbaik yang memberikan biaya produksi paling minimum. Hasil dari penelitian yang telah dilakukan dapat disimpulkan bahwa peramalan yang terbaik adalah dengan menggunakan metode Single Exponential Smoothing menggunakan alpha 0,4 dengan total nilai MAPE sebesar 14\% dan strategi agregat terpilih adalah Chase dan Level Strategy dengan total biaya produksi paling minimum yaitu sebesar Rp 17,940,300,-
\end{abstract}

Kata kunci: Peramalan, Perencanaan Agregat, Strategi Agregat

\begin{abstract}
In general, problems that often arise every company, including PT. Armstrong Industri Indonesia is experiencing difficulties in planning the amount of production according to production capacity so that this study aims to determine the correct forecasting method and the appropriate aggregate strategy for use in production planning on Insulation Sheet A, Foot, and Wire Harness Tie L-80 products that have demand fluctuates. The method used for forecasting the three products is Single Moving Average and Single Exponential Smoothing, while for aggregate planning strategies used include Chase Strategy, Level Strategy and Mixed Strategy, which then choose the best strategy that provides the minimum production cost. The results of the research can be concluded that the best forecasting is to use the Single Exponential Smoothing method using alpha 0.4 with a total MAPE value of $14 \%$ and the selected aggregate strategy is Chase and Level Strategy with the minimum total production cost of Rp. 17,940 ,300,-
\end{abstract}

Keywords: Forecasting, Aggregate Planning, Aggregate Strategy

\section{PENDAHULUAN}

Dalam kegiatan produksi dibutuhkan peramalan dan perencanaan agregat yang tepat untuk mengatasi masalah peramalan permintaan terhadap kemungkinan terjadinya penurunan atau kenaikan penjualan pada periode yang akan datang. Peramalan adalah suatu usaha memperkirakan keadaan dimasa yang akan datang melalui pengujian keadaan dimasa lalu. Sedangkan, perencanaan agregat merupakan suatu metode pendekatan untuk menentukan kuantitas dan waktu produksi pada jangka waktu menengah. Perencanaan Agregat digunakan untuk menekan biaya produksi yang dikeluarkan yang dilihat dari hasil perhitungan peramalan yang terpilih.

Sebagai salah satu perusahaan manufaktur PT. Armstrong Industri Indonesia spesialis teknik presisi terkemuka dan merupakan bagian dari Armstrong Industrial Corp. di Singapura. PT. Armstrong Industri Indonesia merupakan salah satu supplier yang membuat komponen-komponen untuk kebutuhan spare parts perusahaan elektronik. Penerapan metode peramalan dan perencanaan pada PT. Armstrong Industri Indonesia dapat memberikan pengaruh terhadap kapasitas produksi dan biaya-biaya lainnya. 
Perhitungan peramalan dan perencanaan agregat berdasarkan data penjualan masa lalu (1 tahun sebelumnya) dan data biaya tenaga kerja, biaya material, jumlah tenaga kerja, dan lain-lain. metode peramalan dengan menggunakan Metode Single Moving Average dan Single Exponential Smoothing untuk menghitung peramalan penjualan dari PT. Armstrong Industri Indonesia. Dalam menentukan metode yang digunakan dapat dilihat dari pola grafik agregat penjualan PT. Armstrong Industri Indonesia dari bulan Oktober 2017 sampai dengan Januari 2019. Setelah diperoleh hasil dari metode peramalan yang optimal yang dilihat dari nilai MAPE (Mean Absolute Percentage Error) terkecil, dilanjutkan dengan menghitung perencanaan agregat. Pada perhitungan perencanaan agregat menggunakan metode chase strategy, level strategy, dan mixed strategy untuk mendapatkan hasil biaya minimum pada biaya produksi, tenaga kerja, dan lain-lain pada PT. Armstrong Industri Indonesia.

\section{TINJAUAN PUSTAKA}

\section{Metode Peramalan}

Pemilihan model peramalan tergantung pada pola data dan horizon waktu dari peramalan. Model peramalan pada dasarnya terbagi ke dalam tiga kategori yaitu pertimbangan, ekstrapolasi dan kausal. Pertimbangan merupakan model kualitatif, ekstrapolasi dan kausal dikategorikan sebagai model kuantitatif. Metode ekstrapolasi sering disebut juga sebagai Metode Deret Waktu yang menggunakan sekumpulan berdasarkan interval waktu tertentu [1].

1. Exponential Smoothing

Eksponensial Smoothing merupakan metode peramalan rata-rata bergerak dengan pembobotan yang canggih, namun cukup mudah untuk digunakan [2]. Maka ditarik kesimpulan bahwa Metode Exponential Smoothing merupakan metode peramalan rata-rata bergerak dengan pembobotan dan menggunakan pencatatan data masa lalu. Ramalan dari Exponential Smoothing didapat dengan menggunakan persamaan berikut [3],[4],[5]:

$$
F_{t}=F_{t-1}+\alpha\left(A_{t-1}-F_{t-1}\right)
$$

Keterangan:

$$
\begin{array}{ll}
F_{t}: \text { Nilai prediksi untuk periode } \mathrm{t} \\
F_{t-1}: \text { Nilai prediksi untuk periode sebelumnya (t-1) } \\
\alpha \quad: \text { Konstanta pemulusan } \\
A_{t-1}: \text { Nilai aktual untuk periode sebelumnya }(\mathrm{t}-1)
\end{array}
$$

\section{Moving Average}

Peramalan dengan Metode Moving Average atau rata-rata bergerak dilakukan dengan mengambil sekelompok nilai pengamatan, mencari rata-rata yang kemudian nilai rata-rata tersebut digunakan sebagai ramalan untuk periode berikutnya. Secara sistematik Moving Average didapat dengan menggunakan persamaan berikut [3],[4],[5]:

$$
S_{t+1}=\frac{X_{t}+X_{t-1}+\ldots X_{t-n}+1}{n}
$$

Keterangan:

$S_{t+1}:$ Nilai prediksi untuk periode $\mathrm{t}+1$

$X_{t} \quad$ : Data pada periode $\mathrm{t}$

n : Jangka waktu Moving Average

Nilai n merupakan banyaknya periode dalam Moving Average [6].

\section{Ketepatan Metode}

Dalam peramalan, ketetapan dipandang sebagai kriteria penolakan dalam memilih suatu metode peramalan. Dengan ini ketepatan metode berfungsi untuk mengukur 
kesesuaian suatu metode peramalan yang memperoleh sebuah data yang telah diolah [7]. Berikut merupakan beberapa ukuran ketetapan metode yang sering digunakan, seperti:

1. Ukuran Statistik Standar

Jika Xi merupakan data aktual untuk periode $i$ dan $F i$ merupakan ramalan untuk periode yang sama, maka $e$ atau kesalahan didefinisikan menggunakan persamaan (3).

$$
e=X i-F i
$$

Lalu mencari nilai tengah galat absolut metode MAE (Mean Absolute Error) menggunakan persamaan berikut:

$$
M A E=\sum_{i=1 \ldots n}^{n} \frac{|e i|}{n}
$$

2. Ukuran-ukuran Relatif

Nilai tengah galat persentase absolut metode MAPE (Mean Absolute Percentage Error) menggunakan persamaan berikut:

$$
M A P E=\sum_{i=1 \ldots n}^{n} \frac{|P E t|}{n}
$$

\section{Strategi Perencanaan Agregat}

Terdapat tiga strategi dasar dalam perencanaan agregat berdasarkan trade off antara biaya yang berkaitan dengan kapasitas produksi, biaya inventori dan biaya backlog, yaitu [8]:

\section{Level strategy (Level Production)}

Strategi yang ditempuh dengan cara menjaga tingkat output, produksi dan tenaga kerja yang konstan. Ciri-ciri Level Strategy adalah mempertahankan tingkat produksi yang tetap dan memfluktuasikan tingkat persediaan, order backlogs dan lost sales.

\section{Chase strategy (Chase Demand)}

Strategi yang digunakan untuk mencapai tingkat output bagi setiap periode yang memenuhi peramalan permintaan untuk periode tersebut. Strategi ini digunakan untuk meminimalkan dan menstabilkan level inventori. Ciri-ciri Chase Strategy adalah memadankan tingkat produksi dengan tingkat permintaan, menambah/mengurangi tenaga kerja sesuai dengan tingkat permintaan dan jumlah tenaga kerja tetap, tetapi jam kerja tidak tetap

\section{Mixed Strategy}

Strategi ini merupakan kombinasi antara level strategy dan chase strategy. Ciri-ciri Mixed Strategy adalah menggabungkan tingkat produksi dengan tingkat permintaan tetap dan menggabungkan dari dua metode level dan chase tingkat persediaan, order backlogs dan lost sales.

\section{HASIL DAN PEMBAHASAN}

Pengumpulan data penjualan terhadap ketiga produk (Insulation Sheet A, Foot, dan Wire Harness Tie L-80) yang diperoleh dari sumber data-data historis yang diakses dari data perusahaan PT. Armstrong Industri Indonesia yang tersimpan di database pada komputer. Data penjualan untuk produk Insulation Sheet A, Foot, dan Wire Harness Tie L80 selama periode September 2017 sampai dengan Januari 2019 dapat dilihat pada Tabel 1. 
Analisis Perencanaan Produksi pada PT. Armstrong Industri Indonesia dengan Metode Forecasting dan Agregat Planning

Fristha Ayu Reicita

Tabel 1. Data Penjualan Insulation Sheet A, Foot, dan Wire Harness Tie L-80

September 2017 - Januari 2019 (dalam unit)

\begin{tabular}{cccccc}
\hline \multirow{2}{*}{ No. } & \multirow{2}{*}{ Periode } & \multicolumn{3}{c}{ Produk } & \multirow{2}{*}{ Agregat } \\
\cline { 3 - 5 } & Insulation Sheet A & Foot & Stopper Support A & 1259140 \\
\hline 5 & Oct-17 & 537600 & 618400 & 103140 & 1128320 \\
6 & Nov-17 & 370800 & 650000 & 107520 & 811540 \\
7 & Dec-17 & 508800 & 232000 & 70740 & 656860 \\
8 & Jan-18 & 445200 & 124400 & 87260 & 780240 \\
9 & Feb-18 & 471600 & 214400 & 94240 & 841760 \\
10 & Mar-18 & 510000 & 240000 & 91760 & 994910 \\
11 & Apr-18 & 600000 & 300000 & 94910 & 809985 \\
12 & May-18 & 453600 & 240000 & 116385 & 699815 \\
13 & Jun-18 & 439200 & 200000 & 60615 & 865400 \\
14 & Jul-18 & 500400 & 230000 & 135000 & 957200 \\
15 & Aug-18 & 499200 & 320000 & 138000 & 886020 \\
16 & Sep-18 & 495600 & 260000 & 130420 & 8802907 \\
17 & Oct-18 & 505200 & 500000 & 145093 & 550160 \\
18 & Nov-18 & 499200 & 250000 & 132007 & 880900 \\
19 & Dec-18 & 398400 & 80000 & 71760 & \\
20 & Jan-19 & 600000 & 170000 & 110900 & \\
\hline
\end{tabular}

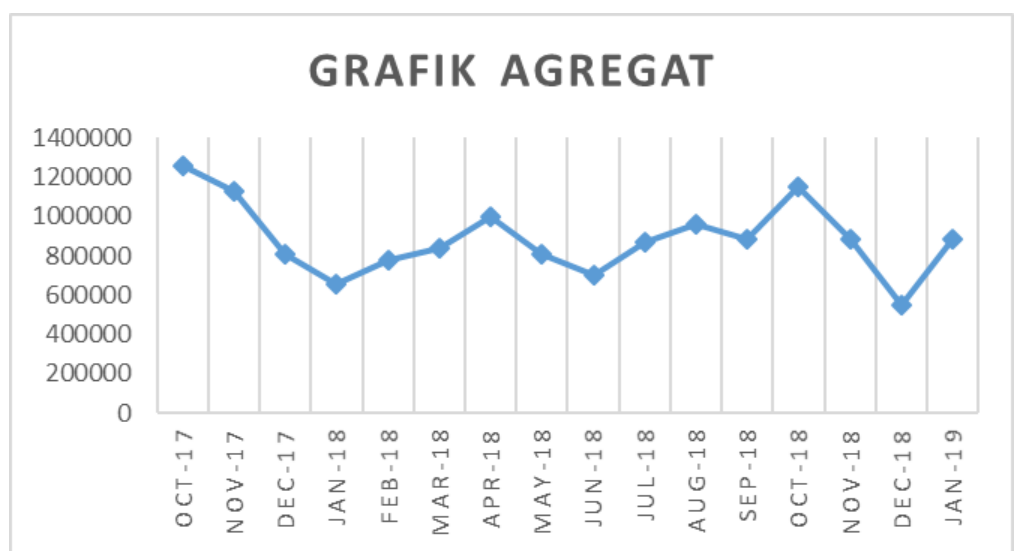

Gambar 3. Grafik Hasil Data Agregat Produk Insulation Sheet A, Foot, dan Wire Harness Tie L-80 pada PT. Armstrong Indonesia

Berdasarkan pola data yang ditampilkan dalam Gambar 3, dari hasil agregat dari ketiga produk PT. Armstrong Industri Indonesia terhadap 20 bulan sebelumnya menunjukkan bahwa grafik tersebut masuk ke dalam pola data horizontal atau stasioner. Maka peneliti mengolah data permintaan terhadap tiga produk dengan menggunakan Metode Single Moving Average dan Single Exponential Smoothing.

\section{Metode Peramalan}

Metode peramalan yang digunakan adalah Single Exponential Smoothing dan Single Moving Average, metode ini digunakan berdasarkan pola grafik yang diketahui pada pengelompokan dua jenis produk yaitu pola horizontal sehingga penggunaan dua metode tersebut akan lebih tepat dalam perhitungan peramalan.

\section{Single Exponential Smoothing}

Data penjualan periode September 2017 sampai dengan Januari 2019 digunakan untuk menghitung jumlah produksi untuk peramalan 6 bulan kedepan dengan menggunakan metode Single Exponential Smoothing berdasarkan data historis pada produk Insulation Sheet A, Foot, dan Wire Harness Tie L-80. Dalam metode ini menggunakan nilai $\alpha$ secara acak sebagai nilai bobot adalah $(\alpha=0,1),(\alpha=0,2)$, dan $(\alpha=0,4)$ dapat dilihat pada Tabel 2. 
Tabel 2. Hasil Perhitungan Peramalan Single Exponential Smoothing

\begin{tabular}{|c|c|c|c|c|c|c|c|c|c|c|c|c|c|c|}
\hline \multirow[b]{2}{*}{ No } & \multirow[b]{2}{*}{$\begin{array}{c}\text { Periode } \\
\mathrm{t}\end{array}$} & \multirow{2}{*}{$\begin{array}{c}\text { Data } \\
\text { Permintaan } \\
\text { xt }\end{array}$} & \multicolumn{3}{|c|}{ Perkiraan } & \multicolumn{3}{|c|}{ Penyimpangan Perkiraan } & \multicolumn{3}{|c|}{ Error (MAE) } & \multicolumn{3}{|c|}{ Absolute Percentage Error (PEI) } \\
\hline & & & $\begin{array}{c}\alpha=0,1 \\
F_{+1}\end{array}$ & $\begin{array}{c}\alpha=0,2 \\
F_{+1}\end{array}$ & $\begin{array}{c}\alpha=0,4 \\
F_{+1}\end{array}$ & $\begin{array}{c}\alpha=0,1 \\
E^{\wedge}{ }^{\wedge} 2\end{array}$ & $\begin{array}{c}\alpha=0,2 \\
E^{\wedge}{ }^{\wedge} 2\end{array}$ & $\begin{array}{c}\alpha=0,4 \\
E^{\wedge} \wedge 2\end{array}$ & $\alpha=0,1$ & $\alpha=0,2$ & $\alpha=0,4$ & $\alpha=0,1$ & $\alpha=0,2$ & $\alpha=0,4$ \\
\hline 1 & Oct-17 & 1259140 & 1259140.00 & 1259140.00 & 1259140.00 & - & 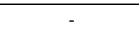 & - & - & - & - & - & - & - \\
\hline 2 & Nov-17 & 1128320 & 1259140.00 & 1259140.00 & 1259140.00 & 17113872400.00 & 17113872400.00 & 17113872400.00 & 130820.00 & 130820.00 & 130820.00 & $12 \%$ & $12 \%$ & $12 \%$ \\
\hline 4 & Jan-18 & 656860 & 1202606.20 & 1148688.80 & 1048703.20 & 297838914814.44 & 241895568509.44 & 153541093386.24 & 545746.20 & 491828.80 & 391843.20 & $83 \%$ & $75 \%$ & $60 \%$ \\
\hline 5 & Feb-18 & 780240 & 1148031.58 & 1050323.04 & 891965.92 & 135270646318.90 & 72944848495.64 & 12482681199.85 & 367791.58 & 270083.04 & 111725.92 & $47 \%$ & $35 \%$ & $14 \%$ \\
\hline 6 & Mar-18 & 841760 & 1111252.42 & 996306.43 & 847275.55 & 72626165515.43 & 23884599643.93 & 30421313.86 & 269492.42 & 154546.43 & 5515.55 & $32 \%$ & $18 \%$ & $1 \%$ \\
\hline 9 & Jun-18 & 699815 & 1048825.98 & 939036.77 & 866997.36 & 121808661115.79 & 57227056765.30 & 27949941238.38 & 349010.98 & 239221.77 & 167182.36 & $50 \%$ & $34 \%$ & $24 \%$ \\
\hline 10 & Jul-18 & 865400 & 1013924.88 & 891192.42 & 800124.42 & 22059639406.96 & 665248854.51 & 4260901926.70 & 148524.88 & 25792.42 & 65275.58 & $17 \%$ & $3 \%$ & $8 \%$ \\
\hline 11 & Aug-18 & 957200 & 999072.39 & 886033.93 & 826234.65 & 1753297066.65 & 5064608830.68 & 17151923077.81 & 41872.39 & 71166.07 & 130965.35 & $4 \%$ & $7 \%$ & $14 \%$ \\
\hline 12 & Sep-18 & 886020 & 994885.15 & 900267.15 & 878620.79 & 11851621154.53 & 202981222.44 & 54748314.63 & 108865.15 & 14247.15 & 7399.21 & $12 \%$ & $2 \%$ & $1 \%$ \\
\hline 13 & Oct-18 & 1150293 & 983998.64 & 897417.72 & 881580.47 & 27653815459.55 & 63945908096.79 & 72206421760.18 & 166294.36 & 252875.28 & 268712.53 & $14 \%$ & $22 \%$ & $23 \%$ \\
\hline 14 & Nov-18 & 881207 & 1000628.07 & 947992.77 & 989065.48 & 14261392558.12 & 4460339693.86 & 11633452625.54 & 119421.07 & 66785.77 & 107858.48 & $14 \%$ & $8 \%$ & $12 \%$ \\
\hline 20 & May-19 & - & 22522560.76 & 20696937.52 & 19798328.46 & - & - & - & - & - & - & - & - & - \\
\hline 21 & Jun-19 & - & 112612803.82 & 103484687.59 & 98991642.31 & - & - & - & - & - & - & - & - & - \\
\hline \multirow[t]{4}{*}{22} & Jul-19 & - & 675676822.94 & 620908125.56 & 593949853.87 & - & - & - & - & - & - & - & - & - \\
\hline & & & Total & & & 1185853496868.97 & 840264645723.77 & 669475854392.56 & 3539588.41 & 2737265.43 & 2516476.29 & $468 \%$ & $363 \%$ & $326 \%$ \\
\hline & & & MAE & & & & & & 153895.15 & 119011.54 & 109412.01 & & & \\
\hline & & & MAPE & & & & & & & & & $20 \%$ & $16 \%$ & $14 \%$ \\
\hline
\end{tabular}

\section{Single Moving Average}

Perhitungan Metode Moving Average dipilih karena didasari pada pola data grafik hasil data agregat yang menunjukan pola data horizontal atau stasioner. Tabel 3 merupakan hasil perhitungan peramalan 6 bulan kedepan dengan menggunakan metode Single Moving Average berdasarkan data historis penjualan dari September 2017 sampai dengan Januari 2019 pada produk Insulation Sheet A, Foot, dan Wire Harness Tie L-80.

Tabel 3. Hasil Perhitungan Peramalan Single Moving Average

\begin{tabular}{cccccc}
\hline No. & Periode & $\begin{array}{c}\text { Data } \\
\text { Permintaan } \\
\text { xt }\end{array}$ & $\begin{array}{c}\text { Perakiraan 3 } \\
\text { Bulanan } \\
\text { Ft }\end{array}$ & $\begin{array}{c}\text { Error } \\
\text { (ei) }\end{array}$ & $\begin{array}{c}\text { Absolute } \\
\text { Percentage } \\
\text { Error (Pei) }\end{array}$ \\
\hline 1 & Oct-17 & 1259140 & - & - & - \\
2 & Nov-17 & 1128320 & - & - & - \\
3 & Dec-17 & 811540 & - & - & - \\
4 & Jan-18 & 656860 & 1066333.33 & 409473.33 & $62.34 \%$ \\
5 & Feb-18 & 780240 & 865573.33 & 85333.33 & $10.94 \%$ \\
6 & Mar-18 & 841760 & 749546.67 & 92213.33 & $10.95 \%$ \\
7 & Apr-18 & 994910 & 759620.00 & 235290.00 & $23.65 \%$ \\
8 & May-18 & 809985 & 872303.33 & 62318.33 & $7.69 \%$ \\
9 & Jun-18 & 699815 & 882218.33 & 182403.33 & $26.06 \%$ \\
10 & Jul-18 & 865400 & 834903.33 & 30496.67 & $3.52 \%$ \\
11 & Aug-18 & 957200 & 791733.33 & 165466.67 & $17.29 \%$ \\
12 & Sep-18 & 886020 & 840805.00 & 45215.00 & $5.10 \%$ \\
13 & Oct-18 & 1150293 & 902873.33 & 247419.67 & $21.51 \%$ \\
14 & Nov-18 & 881207 & 997837.67 & 116630.67 & $13.24 \%$ \\
15 & Dec-18 & 550160 & 972506.67 & 422346.67 & $76.77 \%$ \\
16 & Jan-19 & 880900 & 860553.33 & 20346.67 & $2.31 \%$ \\
17 & Feb-19 & - & 770755.67 & - & - \\
18 & Mar-19 & - & 1541511.33 & - & - \\
19 & Apr-19 & - & 4624534.00 & - & - \\
20 & May-19 & - & 18498136.00 & - & - \\
21 & Jun-19 & - & 92490680.00 & - & - \\
22 & Jul-19 & - & 554944080.00 & - & - \\
\hline \multicolumn{7}{c}{ Total } & & 2114953.67 & $281.37 \%$ \\
\hline \multicolumn{7}{c}{ MAE } & & 151068.12 & \\
\hline & MAPE & & & $20.10 \%$ \\
\hline
\end{tabular}

\section{Rekapitulasi Hasil Peramalan}

Rekapitulasi dilakukan untuk mempermudah dalam mengetahui kevalidan metode yang digunakan. Hasil rekapitulasi nilai error dapat dilihat pada Tabel 4. 
Analisis Perencanaan Produksi pada PT. Armstrong Industri Indonesia dengan Metode Forecasting dan Agregat Planning

Fristha Ayu Reicita

Tabel 4. Rekapitulasi Hasil Nilai Error

\begin{tabular}{cccc}
\hline Metode Peramalan & MAE & MAPE & Keterangan \\
\hline \multirow{3}{*}{ Single Exponential Smoothing } & 153895.15 & $20.34 \%$ & $\alpha=0,1$ \\
& 119011.54 & $15.76 \%$ & $\alpha=0,2$ \\
& 109412.01 & $14.17 \%$ & $\alpha=0,4$ \\
\hline Single Moving Average & 151068.12 & $20.10 \%$ & \\
\hline
\end{tabular}

Berdasarkan Tabel 4, dapat dilihat bahwa nilai kesalahan atau nilai error terkecil terhadap MAE dan MAPE metode Single Exponential Smoothing merupakan metode peramalan terbaik karena menghasilkan nilai MAE sebesar 109412,01 dan nilai MAPE sebesar $14,17 \%$ yang berarti memiliki nilai bias yang kecil.

Tabel 5. Hasil Peramalan dengan Metode Single Exponential Smoothing

\begin{tabular}{cc}
\hline Periode & Hasil Peramalan \\
\hline Feb-19 & 824930 \\
Mar-19 & 1649861 \\
Apr-19 & 4949582 \\
May-19 & 19798328 \\
Jun-19 & 98991642 \\
Jul-19 & 593949854 \\
\hline
\end{tabular}

Pada Tabel 5 merupakan hasil peramalan untuk 6 bulan mendatang dengan metode peramalan terpilih, yaitu metode Single Exponential Smoothing dengan alpha 0,4 terhitung dari bulan Februari 2019 sampai dengan Juli 2019 untuk ketiga produk (Insulation Sheet A, Foot, dan Wire Harness Tie L-80) pada PT. Armstrong Industri Indonesia.

\section{Strategi Perencanaan Agregat}

Setelah dilakukannya peramalan, hal berikutnya yang dilakukan adalah perencanaan agregat. Dalam perencanaan agregat dilakukannya perhitungan menggunakan tiga strategi yaitu chase, level, dan mixed strategy dalam menentukan strategi produksi perusahaan dari perhitungan permalan sebelumnya. Pada perhitungan perencanaan agregat menggunakan data jumlah tenaga kerja, biaya tenaga kerja, dan biaya material. Berikut pengumpulan data untuk menunjang dalam perhitungan perencanaan agregat dapat dilihat pada Tabel 6.

\begin{tabular}{ccc} 
Tabel 6. Data Penunjang Perencanaan Agregat \\
\cline { 2 - 3 } Data Awal & \multicolumn{2}{c}{35} \\
\cline { 2 - 3 } Pekerja Saat Ini & & - \\
Hiring Cost & $\mathrm{Rp}$ & - \\
Firing Cost & $\mathrm{Rp}$ & - \\
Inventory Cost & $\mathrm{Rp}$ & 630 \\
Gaji Pekerja/org & $\mathrm{Rp}$ & $4,160,000$ \\
Material Cost/unit & $\mathrm{Rp}$ & - \\
Stockout Cost & & - \\
Gaji Lembur/hari & $\mathrm{Rp}$ & 179,740 \\
Produk/pekerja/hari & & \multicolumn{2}{c}{6000} \\
\hline
\end{tabular}

Berdasarkan tabel 6, jumlah tenaga kerja langsung untuk memproduksi tiga produk (Insulation Sheet A, Foot, dan Stopper Support A) adalah sebanyak 35 pekerja yang diperoleh dari total tenaga kerja pada PT. Armstrong Industri Indonesia.

\section{Level Strategy}

Pada Level Strategy jumlah produksi bersifat tetap dan inventori yang timbul dapat digunakan untuk memenuhi kelebihan permintaan produk pada periode tertentu. Berikut adalah hasil perhitungan menggunakan level strategy dapat dilihat pada Tabel 7. 
Tabel 7. Data Hasil Perhitungan Menggunakan Level Strategy

\begin{tabular}{|c|c|c|c|c|c|c|c|c|c|c|c|}
\hline Bulan & Produk/Pekerja & $\begin{array}{c}\text { Produksi } \\
\text { (Unit) }\end{array}$ & Demand (Unit) & $\begin{array}{c}\text { Inventory } \\
\text { (Unit) }\end{array}$ & & Produksi & $\begin{array}{c}\text { Biaya } \\
\text { Inventory }\end{array}$ & & iaya Gaji & & Total Cost \\
\hline Feb-19 & 120000 & 4200000 & 824930 & 3375069.65 & $\mathrm{Rp}$ & $2,646,000,000$ & 0 & $\mathrm{Rp}$ & $145,600,000$ & $\mathrm{Rp}$ & $2,791,600,000$ \\
\hline Mar-19 & 126000 & 4410000 & 1649861 & 2760139.29 & $\mathrm{Rp}$ & $2,778,300,000$ & 0 & $\mathrm{Rp}$ & $145,600,000$ & $\mathrm{Rp}$ & $2,923,900,000$ \\
\hline Apr-19 & 132000 & 4620000 & 4949582 & 329582.12 & $\mathrm{Rp}$ & $2,910,600,000$ & 0 & $\mathrm{Rp}$ & $145,600,000$ & $\mathrm{Rp}$ & $3,056,200,000$ \\
\hline May-19 & 138000 & 4830000 & 19798328 & 14968328.46 & $\mathrm{Rp}$ & $3,042,900,000$ & 0 & $\mathrm{Rp}$ & $145,600,000$ & $\mathrm{Rp}$ & $3,188,500,000$ \\
\hline Jun-19 & 120000 & 4200000 & 98991642 & 94791642.31 & $\mathrm{Rp}$ & $2,646,000,000$ & 0 & $\mathrm{Rp}$ & $145,600,000$ & $\mathrm{Rp}$ & $2,791,600,000$ \\
\hline Jul-19 & 138000 & 4830000 & 593949854 & 589119853.87 & $\mathrm{Rp}$ & $3,042,900,000$ & 0 & Rp & $145,600,000$ & $\mathrm{Rp}$ & $3,188,500,000$ \\
\hline
\end{tabular}

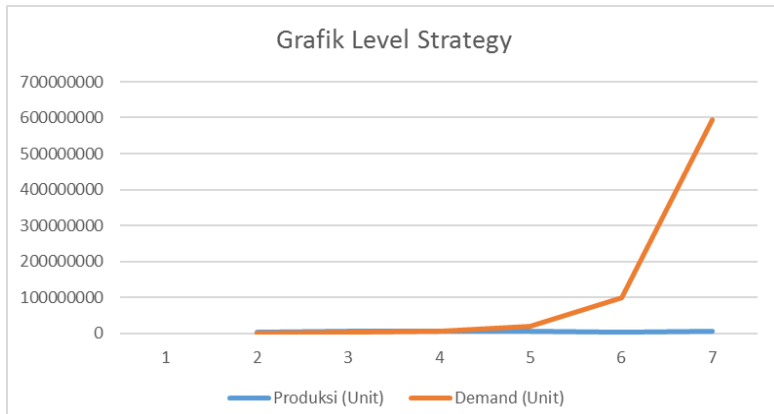

Gambar 4. Grafik Hasil Pengolahan Data Menggunakan Metode Level Strategy

Berdasarkan Tabel 7 serta gambar grafik Level strategy pada Gambar 4 didapatkan hasil bahwa produksi pada periode awal output produksi dapat menyeimbangi permintaan sampai dengan pada periode keempat output produksi mulai tidak memenuhi permintaan konsumen dan dapat dikatakan bahwa PT. Armstrong Industri Indonesia perlu dapat menambah tingkat produksi sehingga dapat memenuhi permintaan. Adapun biaya total produksi pada perencanaan agregat dengan metode Level Strategy ini sebesar Rp $17,940,300,000,-$

\section{Chase Strategy}

Strategi chase yang merupakan metode yang digunakan untuk meminimalkan dan menstabilkan level inventori. Berikut adalah hasil perhitungan menggunakan stategi chase dapat dilihat pada Tabel 8.

Tabel 8. Data Hasil Perhitungan Menggunakan Chase Strategy

\begin{tabular}{|c|c|c|c|c|c|c|c|c|c|c|c|c|c|c|}
\hline Bulan & $\begin{array}{l}\text { Jumlah } \\
\text { Pekerja }\end{array}$ & Hiring & Firing & $\begin{array}{c}\text { Produk/ } \\
\text { Pekerja }\end{array}$ & Produksi (Unit) & Demand (Unit) & Inventory (Unit) & Total & Material Cost & $\begin{array}{c}\text { Total Inventory } \\
\text { Cost }\end{array}$ & & $\begin{array}{l}\text { Total Gaji } \\
\text { Pekerja }\end{array}$ & & tal Produksi \\
\hline Feb-19 & 35 & - & - & 120000 & 4200000 & 824930 & 3375070 & $\mathrm{Rp}$ & $2,646,000,000$ & $\mathrm{Rp}$ & $\mathrm{Rp}$ & $145,600,000$ & $\mathrm{Rp}$ & $2,791,600,000$ \\
\hline Mar-19 & 35 & - & - & 126000 & 4410000 & 1649861 & 2760139 & $\mathrm{Rp}$ & $2,778,300,000$ & $\mathrm{Rp}$ & $\mathrm{Rp}$ & $145,600,000$ & $\mathrm{Rp}$ & $2,923,900,000$ \\
\hline Apr-19 & 35 & - & - & 132000 & 4620000 & 4949582 & 329582 & $\mathrm{Rp}$ & $2,910,600,000$ & $\mathrm{Rp}$ & $\mathrm{Rp}$ & $145,600,000$ & $\mathrm{Rp}$ & $3,056,200,000$ \\
\hline May-19 & 35 & - & - & 138000 & 4830000 & 19798328 & 14968328 & $\mathrm{Rp}$ & $3,042,900,000$ & $\mathrm{Rp}$ & $\mathrm{Rp}$ & $145,600,000$ & $\mathrm{Rp}$ & $3,188,500,000$ \\
\hline Jun-19 & 35 & - & - & 120000 & 4200000 & 98991642 & 94791642 & $\mathrm{Rp}$ & $2,646,000,000$ & $\mathrm{Rp}$ & $\mathrm{Rp}$ & $145,600,000$ & $\mathrm{Rp}$ & $2,791,600,000$ \\
\hline Jul-19 & 35 & - & - & 138000 & 4830000 & 593949854 & 589119854 & $\mathrm{Rp}$ & $3,042,900,000$ & $\mathrm{Rp}$ & $\mathrm{Rp}$ & $145,600,000$ & $\mathrm{Rp}$ & $3,188,500,000$ \\
\hline \multicolumn{2}{|c|}{ Total } & 0 & 0 & & & & & & & \multicolumn{3}{|c|}{ Total } & $\mathrm{Rp}$ & $17,940,300,000$ \\
\hline
\end{tabular}

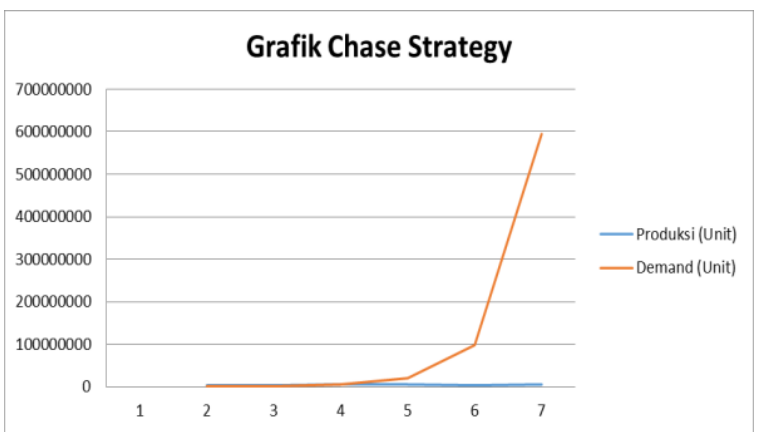

Gambar 5. Grafik Hasil Pengolahan Data Menggunakan Metode Chase Strategy 


\section{Fristha Ayu Reicita}

Berdasarkan Tabel 8 serta grafik pada Gambar 5 dapat dilihat bahwa strategi perburuan ini pada periode awal output produksi dapat menyeimbangi permintaan sampai dengan pada periode keempat output produksi mulai tidak memenuhi permintaan konsumen dan dapat dikatakan bahwa PT. Armstrong Industri Indonesia perlu dapat menambah tingkat produksi sehingga dapat memenuhi permintaan. Adapun biaya total produksi pada perencanaan agregat dengan metode Chase Strategy ini sebesar Rp $17,940,300,000,-$

\section{Mixed Strategy}

Mixed Strategy ini melibatkan pengubahan lebih dari satu variabel yang dapat dikontrol dan merupakan strategi gabungan dari Chase dan Level Strategy. Berikut Tabel 9 adalah hasil perhitungan menggunakan mixed strategy.

Tabel 9. Data Hasil Perhitungan Menggunakan Mixed Strategy

\begin{tabular}{|c|c|c|c|c|c|c|c|c|}
\hline Bulan & $\begin{array}{c}\text { Hari Kerja } \\
\text { Reguler }\end{array}$ & $\begin{array}{c}\text { Hari Kerja } \\
\text { Lembur (days) }\end{array}$ & $\begin{array}{c}\text { Jumlah Produksi } \\
\text { Reg./Pekerja (unit) }\end{array}$ & $\begin{array}{c}\text { Jumlah Produksi } \\
\text { Lembur/Pekerja (unit) }\end{array}$ & $\begin{array}{c}\text { Jumlah Pekerja } \\
\text { Reg. (orang) }\end{array}$ & $\begin{array}{l}\text { Jumlah Pekerja } \\
\text { Lembur (orang) }\end{array}$ & $\begin{array}{l}\text { Total Produksi } \\
\text { Reg.(unit) }\end{array}$ & $\begin{array}{l}\text { Total Produksi } \\
\text { Lembur (unit) }\end{array}$ \\
\hline Feb-19 & 20 & 8 & 120000 & 1000 & 35 & 17 & 4200000 & 17000 \\
\hline Mar-19 & 21 & 8 & 126000 & 1000 & 35 & 9 & 4410000 & 9000 \\
\hline Apr-19 & 22 & 9 & 132000 & 1000 & 35 & 13 & 4620000 & 13000 \\
\hline May-19 & 23 & 9 & 138000 & 1000 & 35 & 10 & 4830000 & 10000 \\
\hline Jun-19 & 20 & 13 & 120000 & 1000 & 35 & 18 & 4200000 & 18000 \\
\hline Jul-19 & 23 & 8 & 138000 & 1000 & 35 & 9 & 4830000 & 9000 \\
\hline
\end{tabular}

Tabel 10. Data Hasil Perhitungan Menggunakan Mixed Strategy (Lanjutan)

\begin{tabular}{|c|c|c|c|c|c|c|c|c|c|c|c|c|}
\hline \multirow{2}{*}{$\begin{array}{c}\begin{array}{c}\text { Total Produksi } \\
\text { Keseluruhan (unit) }\end{array} \\
4217000\end{array}$} & \multirow{2}{*}{$\begin{array}{c}\text { Demand (unit) } \\
824930\end{array}$} & \multirow{2}{*}{$\begin{array}{c}\text { Inventory } \\
\text { (U nit) }\end{array}$} & \multicolumn{2}{|c|}{ Biaya Produksi } & \multicolumn{2}{|c|}{ Biaya Inventori } & \multicolumn{2}{|c|}{ Biaya Lembur } & \multicolumn{2}{|c|}{ Gaji Pekerja } & \multicolumn{2}{|r|}{ Total Biaya } \\
\hline & & & $\mathrm{Rp}$ & $2,656,710,000$ & $\mathrm{Rp}$ & - & $\mathrm{Rp}$ & $3,055,580$ & $\mathrm{Rp}$ & $145,600,000$ & $\mathrm{Rp}$ & $2,805,365,580$ \\
\hline 4419000 & 1649861 & - & $\mathrm{Rp}$ & $2,783,970,000$ & $\mathrm{Rp}$ & - & $\mathrm{Rp}$ & $1,617,660$ & $\mathrm{Rp}$ & $145,600,000$ & $\mathrm{Rp}$ & $2,931,187,660$ \\
\hline 4633000 & 4949582 & - & $\mathrm{Rp}$ & $2,918,790,000$ & $\mathrm{Rp}$ & - & $\mathrm{Rp}$ & $2,336,620$ & $\mathrm{Rp}$ & $145,600,000$ & $\mathrm{Rp}$ & $3,066,726,620$ \\
\hline 4840000 & 19798328 & - & $\mathrm{Rp}$ & $3,049,200,000$ & $\mathrm{Rp}$ & - & $\mathrm{Rp}$ & $1,797,400$ & $\mathrm{Rp}$ & $145,600,000$ & $\mathrm{Rp}$ & $3,196,597,400$ \\
\hline 4218000 & 98991642 & - & $\mathrm{Rp}$ & $2,657,340,000$ & $\mathrm{Rp}$ & - & $\mathrm{Rp}$ & $3,235,320$ & $\mathrm{Rp}$ & $145,600,000$ & $\mathrm{Rp}$ & $2,806,175,320$ \\
\hline 4839000 & 593949854 & - & $\mathrm{Rp}$ & $3,048,570,000$ & $\mathrm{Rp}$ & - & $\mathrm{Rp}$ & $1,617,660$ & $\mathrm{Rp}$ & $145,600,000$ & $\mathrm{Rp}$ & $3,195,787,660$ \\
\hline & \multicolumn{2}{|c|}{ TOTAL } & $\mathrm{Rp}$ & $17,114,580,000$ & & & $\mathrm{Rp}$ & $13,660,240$ & $\mathrm{Rp}$ & $873,600,000$ & Rp & $18,001,840,240$ \\
\hline
\end{tabular}

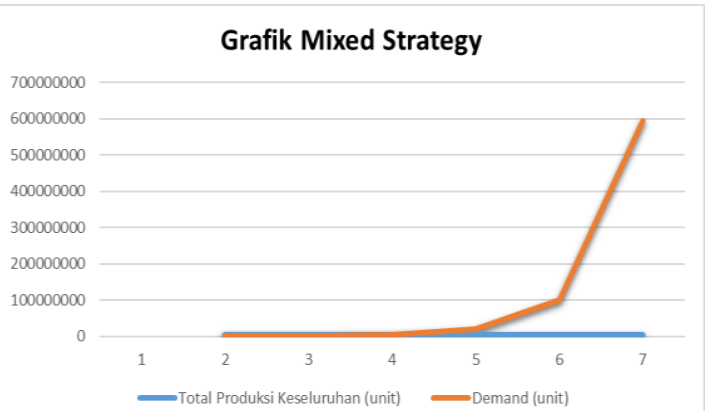

Gambar 4. Grafik Hasil Pengolahan Data Menggunakan Metode Chase Strategy

Berdasarkan Tabel 9 dan 10 serta Gambar 4 mengenai Mixed Strategy adalah tingkat total output produksi yang dihasilkan pada periode awal dapat menyeimbangi permintaan sampai dengan pada periode keempat output produksi mulai tidak memenuhi permintaan konsumen dan dapat dikatakan bahwa PT. Armstrong Industri Indonesia perlu dapat menambah tingkat produksi sehingga dapat memenuhi permintaan. Adapun untuk biaya produksi yang dihasilkan adalah sekitar 2 sampai 3 milyar rupiah selama periode 6 bulan tersebut. Begitu juga dengan total biaya produksi yang cukup besar selama periode 6 bulan tersebut yaitu sebesar Rp 17,114,580,000,- dan total biaya produksi dengan biaya tambahan, seperti biaya lembur dan gaji pekerja mencapai sebesar Rp 18,001,840,240,- 


\section{KESIMPULAN}

Berdasarkan pola data terhadap produk Insulation Sheet A, Foot, dan Wire Harness Tie L-80 diperoleh hasil bahwa pola data ketiga produk tersebut memiliki pola data horizontal atau stasioner, karena pola menunjukkan adanya fluktuasi di sekitar rata-rata konstan. Maka dalam mengolah data penjualan terhadap tiga produk dengan menggunakan metode Single Exponential Smoothing dan Single Moving Average dan untuk ketepatan metode digunakannya nilai error untuk mengetahui kevalidan metode yang digunakan. Dari kedua metode yang digunakan, metode peramalan permintaan terbaik adalah Single Exponential Smoothing dengan nilai MAE sebesar 109412,01 dan nilai MAPE sebesar $14,17 \%$ yang berarti memiliki nilai bias yang kecil.

Sedangkan, dalam pengolahan data yang dilakukan untuk strategi perencanaan agregat yang terpilih adalah menggunakan Chase Strategy dan Level Strategy dengan total biaya terendah dibandingkan dengan strategi lainnya (Mixed Strategy) yaitu sebesar Rp $17,940,300,000,-$

\section{DAFTAR PUSTAKA}

[1].Gaspersz, Vincent., 2002, Production Planing and Inventory Control, PT. Gramedia Pustaka Utama: Jakarta.

[2].Pakaja, F., Naba, A., Purwanto, 2012, Peramalan Penjualan Mobil Menggunakan Jaringan Syaraf Tiruan dan Certainty Factor, Jurnal EECCIS, Vol.6, No.1, Juni 2012. Malang.

[3].Assauri, Sofyan., 1984, Teknik dan Metode Peramalan : Penerapannya Dalam Ekonomi dan Dunia Usaha, Edisi Pertama, Lembaga Penerbit Fakultas Ekonomi Universitas Indonesia, Jakarta.

[4].Makridakis, S., Wheelwright, S.C., McGee, Victor E., 1999, Metode dan Aplikasi Peramalan, Jilid Satu, Edisi 2, Terjemahan Andriyanto, U.S., Abdul, A., Jakarta.

[5].Nugraha, Eucharistia Yacoba., dan Suletra, I Wayan., 2017, Analisis Metode Peramalan Permintaan Terbaik Produk Oxycan pada PT. Samator Gresik, Jurnal IDEC 2017, ISSN: 2579-6429, Mei 2017, Surakarta.

[6].Gaspersz, Vincent., 2005, Production Planing and Inventory Control, PT. Gramedia Pustaka Utama: Jakarta.7

[7].Kusuma, J, M.A., 2000, Statistik Teori dan Aplikasi, Edisi 6 Jilid 1, Erlangga: Jakarta

[8].Sule, Ernie Tisnawati., dan Kurniawan Saefullah., 2008, Pengantar Manajemen, Prenada Media Group: Jakarta. 